\title{
『木造住宅平面図集』及びその改訂版にみる住宅金融公庫の住宅像 THE HOUSING IDEA FOR COMMONS PRESENTED BY THE HOUSING LOAN CORPORATION THROUGH COLLECTIONS OF DRAWINGS OF THE WOODEN STANDARD HOUSE
}

\author{
坪田慎介*1, 勝木祐仁*2, 篠野志郎*3 \\ Shinsuke TSUBOTA, Yuji KATSUKI and Shiro SASANO
}

The aim of this paper is to clarify the housing idea for commons envisioned by the Housing Loan Corporation through drawings of the wooden standard houses, which published 6 times from 1951 to 1975. Through the examination of the plans of the houses, it is clarified that the housing idea was modified according to the change of Japanese life style. Notably the Corporation intended the improvement of Japanese houses for commons by presenting advanced idea in 60 s, when some Japanese embraced the advanced idea while the other persisted in the traditional idea.

Keywords : the Housing Loan Corporation, housing policy, house improvement, standard design

住宅金融公庫, 住宅政策, 住宅改良, 標準設計

\section{1 はじめに}

本研究は、住宅金融公庫 (以下公庫と略す) が融資住宅の質的向 上を目的に行った業務の一つである、標準住宅設計図の作成・頒布 に注目し、公庫が戦後の我が国の住宅形式や住宅観の形成に果たし た役割を明らかにすることを目的としたものである。標準住宅設計 図は、公庫の融資条件に適合する戸建住宅の設計例であり、融資審 査手続きに必要な設計図面一式で構成されたものである。その作成 により公庫は融資住宅建設の円滑化を図るとともに、優良な住宅の 範例を広く一般に提示することも意図していた ${ }^{1)}$ 。こうした形で公

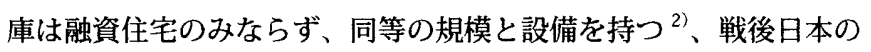
庶民住宅一般のあり方に対して指導的役割を担扔うとしていたと言 える ${ }^{3)}$ 。しかし、公庫の設計図あるいは平面図集をもとに断片的考 察はあるが公庫の住宅像及び当時の庶民住宅像を体系的に分析した

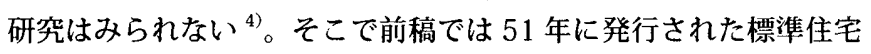
設計図について作成の経緯を明らかにするとともに、51 年に公庫 が発行した『木造住宅平面図集』及び『簡易耐火・耐火構造住宅平 面図集』に所収されたそれらの平面図の分析を行い、草創期の公庫 が抱いていた戦後日本の住宅像について検討を行った ${ }^{5)}$ 。それらの 平面図集には、様々な住宅規模、あらゆる敷地方位への対応に加え、 施主それぞれの住宅観、住様式に対応できるよう、伝統的で通俗性
を持つものから、戦後の新しい住宅のあり方を標榜する斬新なもの まで、多種多様な設計例が含まれていた。標準住宅設計図の作成に あたり、公庫は自らの設計案の他、民間建築家の案や住宅設計競技 の当選案を採用しており、設計例に多様性をもたらせることを重要 な方針としていたと言える。

ところで標準住宅設計図は 79 年まで発行されたが、その間に新 たな設計例が追加されるとともに、一部の設計例は削除されていっ た。その加除は日本人の住宅に対する要求の変化に応じ、公庫が日 本の住宅のあるべき姿を捉え直していったことの現れと理解するこ とができる。標準住宅設計図は紛失あるいは散逸しており、その全 貌に触れることはできないが、51 年に刊行されたものと同様、標 準住宅設計図の平面図をまとめて掲載した平面図集が数度にわたつ て発行されている ${ }^{6)}$ 。そのため平面図集が発行された各時期に頒布 されていた全ての標準設計図について、平面図の全容を知ることが できる。なお平面図集は、木造戸建住宅と簡易耐火・耐火構造戸建 住宅についてそれぞれ刊行されたが、積極的に改訂が行われたのは、 木造の標準住宅設計図を所収した平面図集であり、51 年刊行の『木 造住宅平面図集』の系譜として捉えられるものであった ${ }^{7)}$ 。公庫 は戦後日本において、簡易耐火・耐火構造戸建住宅より、木造戸建 住宅が適切と考え、その普及を重視したと言える。
*1 東京工業大学総合理工学研究科人間環境システム專攻 博士後期課程 · 修士 (工学)

*2 日本工業大学 特別研究員, 学術振興会 特別研究員 ·搏士 (工学)

*3 東京工業大学総合理工学研究科人間環境システム専攻 教授. 工博
Graduate Student, Department of Built Environment, Interdisciplinary Graduate School of Science and Engineering, Tokyo Institute of Technology, M. Eng.

Visiting Research Fellow, Nippon Institute of Technology, Research Fellow of the Japan Society for the Promotion of Science, Dr. Eng.

Prof., Department of Built Environment, Interdisciplinary Graduate School of Science and Engineering, Tokyo Institute of Technology, Dr. Eng. 
そこで本稿では標準住宅設計図の頒布が行われた 51 年から 79 年までの間に公庫が刊行した『木造住宅平面図集』及びその改訂 版全 6 集を研究対象とし、それらに揭載された木造の標準住宅設計 図の平面図の変遷を明らかにし、その変遷の背景や標準住宅設計図 に対する社会的評価についての考察を踏まえ、公庫が描いた戦後 我が国の住宅像について検討を行う ${ }^{8)}$ 。本研究における基本史料は 『木造住宅平面図集』及びその改訂版とし ${ }^{97} 、$ 公庫の年史 ${ }^{10)}$ 、機関

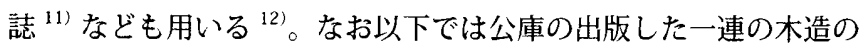
平面図集を木造平面図集、各木造平面図集をその刊行年によって、 $\bigcirc \bigcirc$ 年版（西暦下 2 桁）と記す。

\section{2 平面图集の沿革と改訂の背景}

木造平面図集の刊行年および標題を表 1 に示した。改訂版には それぞれ改訂の背景が記されており、そこに示された主な項目を併 せて示した。まず 55 年版では「標準住宅設計図」を充実させる こと」が目的に揭げられている ${ }^{13)}$ 。「充実」の具体的な内容が述べ られていないが、 51 年版にはなかった新しい設計例が多く加えら れており、より多様な設計例の揭載が目指されたと言える。 55 年 版から一部の設計例について設計趣旨及び透視図の掲載が行われて おり、編集方針に一部変更があったと言える。57 年版では、住宅 に対する社会的要求の変化が改訂の背景として述べられており、具 体的には家事労㗢の軽減、就寝分離、設備的革新への対応が目的 とされている ${ }^{14)}$ 。経済白書において「もはや戦後ではない」と諚 われた翌年であり ${ }^{15)}$ 、住宅の戦後復興という段階を超え、さらに 質の高い住宅像が求められたと考えられる。また改訂を通じて、単 に住宅の標準的なあり方を示すのではなく、新しい社会的要求に 応じた「新しい設計例」 ${ }^{16)}$ を提示する意図が示されている。続く 64 年版では、電気製品の普及、洋風化に伴う居住形式の変化、住 宅規模の拡大に伴う住居水準の向上への対応が改訂の理由に挙げら れている ${ }^{17 \%} 。 66$ 年版では寸法表記が尺貫法からメートル法に変更 されるとともに、新しい社会的要求への対応が改めて改訂の目的と された ${ }^{18)}$ 。社会的要求の変化への対応、すなわち設備的革新や住 宅規模の拡大という課題は、75 年の最後の改訂にも受け継がれて いる ${ }^{19)}$ 。しかし、設計図揭載の平面図集の販売は 79 年に廃止され ており、その理由は、建築基準法上の確認申請制度の改正により、 $100 \mathrm{~m}^{2}$ 以上というより規模の大きい住宅の設計図の頒布が困難に なったこととされる ${ }^{20)}$ 。このように木造平面図集の改訂は、50 年 代から 60 年中頃までは生活様式の変化への対応を主な目的に、60 年代中頃から 70 年代には設備的革新や規模拡大への対応を主な目 的に行われたとみられる。

各平面図集に掲載された設計例の事例数と設計例の加除の動向を 図 1 に示した。 51 年版に 240 件が掲載されていたのに対し、55 年版では新しい設計例が 116 件加えられ、削除されたものも 6 件 あるが、事例数は 350 件に増加している。従来の事例の大半を残 したまま、より多くの選択肢が利用者に与えられたと言える。

一方、57 年版、64 年版では、事例数がそれぞれ 300 件、222 件に減少している。ただしこの減少は単なる設計例の絞り込みの結 果ではなかった。 57 年の改訂についてみると、旧版から 109 件の 設計例が削除される一方、新たな設計例が 60 件加えられている。 また、削除された 109 件についてみると、そのうち 51 件は 55 年
の改訂で新たに加えられたばかりの事例であった。このように、公 庫は各時期における標準住宅設計図のあるべき姿を模索しながら、 設計例の入れ替えを柔軟に行ったと言える。57 年版には標準住宅 設計図の加除に関する指針について、購入の申込が多い設計例を優 先的に残したことが記されている ${ }^{21}$ 。当時住宅建設を具体的に考 えていた人々の住宅に対する要求が、木造住宅平面図集揭載の住宅 例に反映していたと言える。

続く 66 年の改訂では、メートル法表記への移行に伴い、所収の 設計例が一新されており、旧版と同一の図面は含まれていない。標 準住宅設計図の全面的改訂が行われたと言える。ただし設計例の比 較検討を行ったところ、66 年版における全 187 件中 36 件は、旧 版にあたる 64 年版所収の設計例に一部改変を加えただけのもので あった ${ }^{22)}$ 。75 年の改訂では、旧版から 5 件の削除、1 4 件の追加 が行われ、187 件から 196 件に設計例の増加が行われている。

このように公庫は、社会的要求の変化に応じた住宅設計例を提 示することで、住宅建設の当事者である当時の日本人が実際にどの ような設計例を好むかを考慮しつつ、各時期に相応しい融資住宅の 姿を模索していったと言える。標準住宅設計図の新規追加や削除、 それに伴う木造住宅平面図集の改訂の繰り返しは、そうした公庫の、 模索の過程を表すものと言える。

\section{3 平面図集掲載の設計例の概要と変㚖}

次に各改訂版に揭載の住宅の平面図を検討する。まず、床面積 についてみると（表 2)、当初の 51 年版に所収された設計例の床 面積の範囲が 9 〜 25 坪であったのに対し、66 年版以降では約 30 〜 $100 \mathrm{~m}^{2}$ (約 9〜30 坪) となり、上限が拡大している。これは 公庫が 65 年に融資対象住宅の床面積の上限を 30 坪から $120 \mathrm{~m}^{2}$ (約 36 坪）に引き上げたことへの対応と考えられる ${ }^{23)}$ 。床面積の平均 は、 51 年版の 16.5 坪から 75 年版の $63.1 \mathrm{~m}^{2}$ (約 18.8 坪) まで漸 次増加している。設計例を規模により、3 坪毎の階級に分け、各階 級の全体に占める割合をみると、各改訂版とも 15 坪から 21 坪の 範囲に多くの設計例が集中している(図 2)。しかし 51 年版及び 55 年版では 15 坪以上 18 坪末満の割合が最多であるのに対して、 57 年版以降では 18 坪以上 21 坪末満の割合が最多となっているほ か、全般的に小規模の設計例が減少し、比較的大きな規模の設計例 の割合が増加している ${ }^{24)}$ (図 2)。64 年版以降改訂の目的として、 規模水準の向上が揭げられており、60 年代中頃以降、標準住宅設 計図の加除の主な目的として、総体的な規模の拡大があったと考え られる。なかでも、75 年の改訂では、削減された設計例の全てが 24 坪以下であったのに対して、追加された設計例は全て 24 坪以 上であったことから、規模の拡大が最も主要な改訂理由であったと 言える。このように、平面図集に関して、公庫は $15 \sim 21$ 坪前後 を変わらず標準的な住宅の広さと捉えていたと考えられるが、一方 で小規模な住宅を減らし、比較的規模の大きい住宅を増やすことで、 規模の向上が図られたことが窅える。

階数についてみると、 51 年版の設計例が全て平屋建てであった のに対し、55 年版からは 2 階建の住宅が所収されている。55 年 版では新たに所収された設計例 116 件のうち 50 件が 2 階建であり、 2 階建の採用が改訂の大きな特徴と言える。その後の改訂でも 2 階 建の割合が増加しており、75 年版では新規追加の 14 件全てが 2 
表 1 木造住宅の標準住宅設計㘣に関する平面図集の標題及び改訂の背景

\begin{tabular}{|c|c|c|c|c|c|c|c|c|}
\hline 平面図集名 & $\begin{array}{l}\text { 発行 } \\
\text { 年 }\end{array}$ & $\begin{array}{l}\text { 住宅の } \\
\text { 要求の } \\
\text { 変化 }\end{array}$ & $\begin{array}{l}\text { 住宅水 } \\
\text { 隼の向 } \\
\text { 上 }\end{array}$ & $\begin{array}{l}\text { 設計図 } \\
\text { の充実 }\end{array}$ & $\begin{array}{l}\text { 家事の } \\
\text { 軽隇 }\end{array}$ & 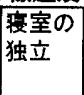 & $\begin{array}{l}\text { 設備の } \\
\text { 向上 }\end{array}$ & $\begin{array}{l}\text { 電気製普 } \\
\text { 及 }\end{array}$ \\
\hline 木造住宅平面図集 & 1951 & & & & & & & \\
\hline 木造住宅平面图集 & 1955 & & & 0 & & & & \\
\hline 木造住宅平面図集 & 1957 & 0 & & & 0 & 0 & 0 & \\
\hline 木造住宅平面图集 & 1964 & 0 & 0 & & & & & 0 \\
\hline メートル法によるる住铎平面图稪 & 1966 & 0 & & & & & & \\
\hline 住宅平面図集改訂版 & 1975 & & 0 & & & & 0 & \\
\hline
\end{tabular}

表 2 平面図集の設計例の概要（階数、規模、居室数、設備）

\begin{tabular}{|c|c|c|c|c|c|c|c|}
\hline 発行年 & & 1951 & 1955 & 1957 & 1964 & 1966 & 1975 \\
\hline 総事例数 & & 240 & 350 & 300 & 222 & 185 & 196 \\
\hline 階数 & 平屋建 & 240 & 300 & 261 & 188 & 139 & 141 \\
\hline & 2階建 & & 50 & 39 & 34 & 46 & 55 \\
\hline 規模 & 規模範囲(坪) & $9 \sim 25$ & $9 \sim 25$ & $9 \sim 25$ & $9 \sim 25$ & $\begin{array}{l}9 \sim 30(30 \\
\left.\sim 98 \mathrm{~m}^{2}\right)\end{array}$ & $\begin{array}{l}9 \sim 30(30 \\
\left.\sim 98 \mathrm{~m}^{2}\right)\end{array}$ \\
\hline & 規模平均 (坪) & 16.5 & 17.4 & 17.9 & 17.9 & $\begin{array}{l}18.2 \\
\left(60.0 \mathrm{~m}^{2}\right)\end{array}$ & $\begin{array}{l}8.8 \\
\left(62.1 \mathrm{~m}^{2}\right) \\
\end{array}$ \\
\hline 居室数※1 & 居室数2 & 41 & 41 & 33 & 15 & 14 & 14 \\
\hline & 居室数3 & 126 & 174 & 150 & 106 & 84 & 82 \\
\hline & 居室数4 & 66 & 126 & 104 & 87 & 72 & 74 \\
\hline & 居室数5 & 6 & 9 & 13 & 13 & 17 & 26 \\
\hline & 居室数数平均 & 3.1 & 3.3 & 3.3 & 3.4 & 3.5 & 3.6 \\
\hline 設備構成 & 浴室 & 196 & 296 & 255 & 211 & 185 & 196 \\
\hline & 洗面室 & 112 & 120 & 101 & 87 & 152 & 141 \\
\hline
\end{tabular}

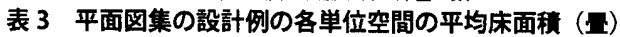

\begin{tabular}{|c|c|c|c|c|c|c|}
\hline 発行年 & 居室(全体) & 居室(最大) & 便所 & 台所 & 浴室 & 洗面臺 \\
\hline 1951 & 5.9 & 6.8 & 1.0 & 3.0 & 1.8 & \begin{tabular}{|l}
0.8 \\
\end{tabular} \\
\hline 1955 & 6.0 & 6.8 & 1.0 & 3.0 & 1.7 & 0.8 \\
\hline 1957 & 5.9 & 6.7 & 1.0 & 3.1 & 1.7 & 0.9 \\
\hline 1964 & 5.9 & 6.6 & 1.0 & 3.1 & 1.7 & 0.9 \\
\hline 1966 & 5.9 & 6.4 & 0.9 & 3.5 & 1.6 & 1.3 \\
\hline 1975 & 5.9 & 6.4 & 1.0 & 3.6 & 1.6 & 1.2 \\
\hline
\end{tabular}

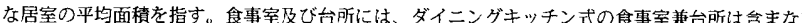

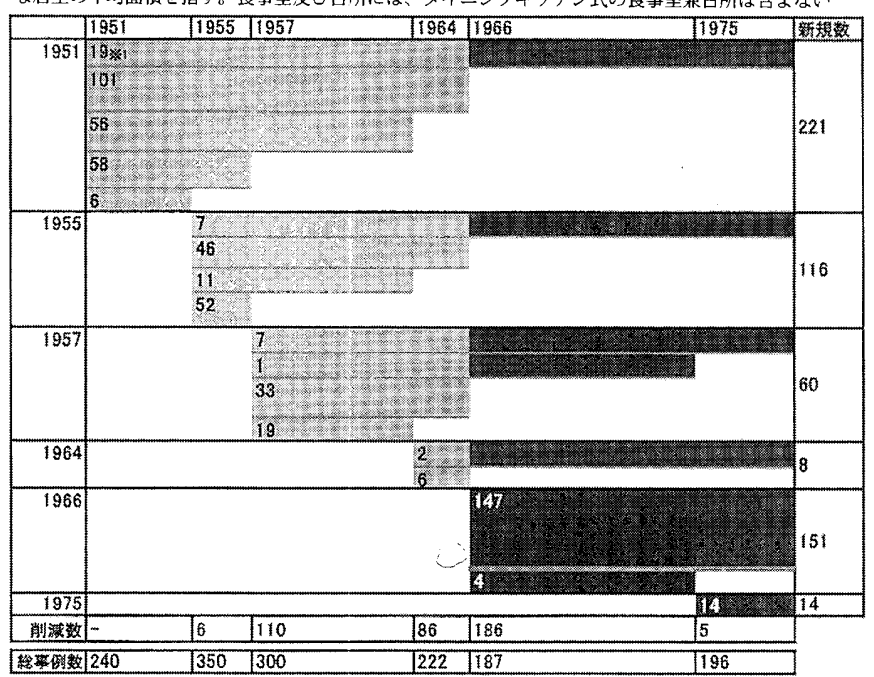

図 1 平面図集の設計例の加除による事例数の变遷

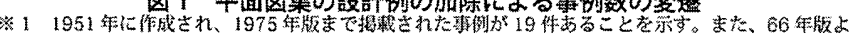

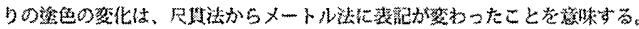

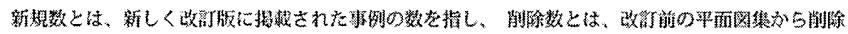

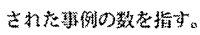

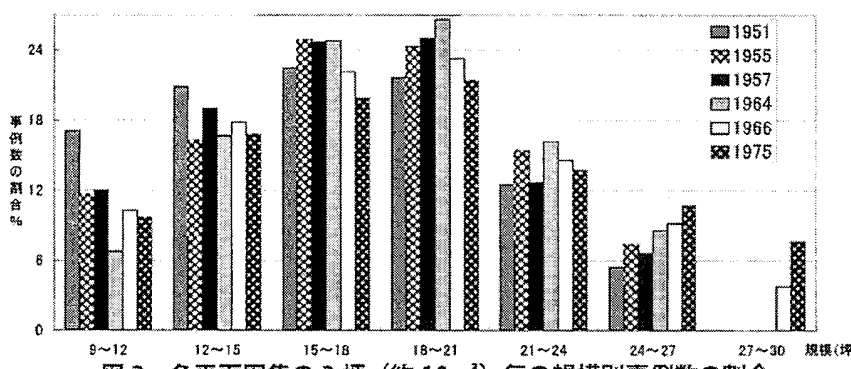

图2 各平面图集の3 坪(約 $\left.10 \mathrm{~m}^{3}\right)$ 毎の規模別事例数の割合
階建であった。公庫は標準住宅設計図の床面積の搪大を進めたが、 2 階建の設計例を積極的に採用していったと考えられる。

次に食事室や寝室等、居室 ${ }^{25)}$ の数についてみると、全改訂版 を通して居室数 3 のものが最も多い。しかし、その割合は 51 年版 の $53 \%$ か 75 年版の $42 \%$ まで減少している。一方、居室数 4 の 割合は同期間に $28 \%$ から $38 \%$ へと増加し、居室数 3 の割合に迫 つている。また、居室数 2 の割合の減少、居室数 5 の割合の增加 もみられ、居室数の平均值は 51 年から 75 年までの間に 3.1 から 3.6 へと漸次増加している。

設計例に付記された設計趣旨をみると、居室数の増加と関連す るものとして、椅子座式の食事室の設置、寝室の增加、子供室の 設置等が諨われている ${ }^{26)}$ 。室名が記されていない場合でも、台所 に接していることから、食事のための部屋として計画されたと推 察される板の間の部屋も「食事室」とみなし、「食事室」設置の割 合をみると、 51 年版では $24 \%$ とまだ少数であったが、 64 年版の $37.8 \%$ まで潮次增加し、さらに大幅な改訂の行われた 66 年版では $78 \%$ に增加している。特に各改訂版における新規の設計例をみる

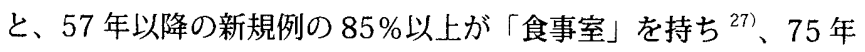
の改訂の新規例である 14 件全てが板の間の「食事室」を持っていた。 また、 57 年に揭げられた寝室の独立は、設計趣旨の中で具体的に は子供室の設置に言い換えられているが 28)、子供室のある例も 51 年版で 7 件と少数であったが、 66 年版では 79 件に上り、各改訂 で継続して採り込まれている。椅子座式の食事室や子供室の設置は 戦前から戦後にかけて住宅改良に関する一連の運動で提唱された平 面形式に一致する ${ }^{29)}$ 。

食事室、子供室が設置されている割合はそれぞれ改訂每に増加 しており、居室数の増加傾向は、これらの室の導入に起因するもの と考えられる。なお 57 年版には改訂の趣旨として、家事労㗢の軽 減や就寝分離が揭げられており、椅子座式の食事室の設置は食寝分 離と家事労働の軽減を目的としたもの ${ }^{30}$ 、寝室や子供室の増加は、 就寝分離を目的としたものと推察される ${ }^{31)}$ 。すなわち、木造住宅 平面図集所収の設計例にみられる居室数の増加は、こうした生活改 善運動の流孔を汲む設計思潮を背景に進められたと考えられる。

ここで居室の面積についてみると、1 部屋の平均面積は、約 6 睤 と各改訂版を通して一定である (表 3)。居間、食事室、茶の間な どの公室で、各住宅で最も大きな部屋の床面積の平均值をみると、 51 年の 6.8 畳から 75 年の 6.4 畳に減少している。一方、台所及 び洗面室の平均面積は拡大している。6 64 年の改訂の目的に、電気 製品の普及への対応が掲げられており、66 年版以降は洗面室に洗 濯機の表記がみられる（図3)。すなわち 60 年代における一般家 庭への電化製品の普及を背景に、洗濯機を置く空間として、洗面室 を拡大させ、冷蔵庫を置く場所を確保するよう台所を拡大させる傾 向があったと言える。これらのことから各改訂でみられる床面積の 増加傾向は、居室及び設備空間を含めた住宅内の各単位空間の面積 を拡大させたためではなく、食寝分離や就寝分離を目的とした所要 室数の増加や、家電製品の増加が主な要因であったと言える。

設備について、浴室の設置された設計例の割合をみると、 51 年 版の $82 \%$ から改訂ごとに増加し、66 年版以降では全ての設計例に 設置がみられる。65 年の融資基準改正により融資住宅に対する浴

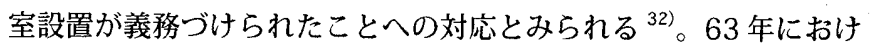


る浴室の全国普及率が $59 \%$ に留まっていたことから ${ }^{33)}$ 、公庫は浴 室の普及について融資基準改正以降はもちろん、51 年当初から先 導的な役割を担っていたと評価できる。洗面室の設置された設計 例の割合も、 51 年版の $47 \%$ から 66 年の $82 \%$ まで増加している。 57 年版で改訂の目的に挙げられたこれらの設備水準の向上も、設 計例の規模拡大の背景と考えられる。

次に平面図集に掲載された設計例の平面形式について検討を行 う。前稿で述べたように、公庫は、 51 年の標準住宅設計図作成に 際し、伝統的な住習慣に即したものから、戦後の新しい生活のあり 方を志向するものまで、様々な生活様式に対応した設計例を含ませ る方針とした。そうして作成された標準住宅設計図は、公庫によっ て大きく「盢の部屋を主とした純日本風なもの」、「板の間の部屋 に主眼をおいた新しい傾向のもの」「「て中間のもの」の3つに分 類されるものであった ${ }^{34)}$ 。すなわち公庫は施主それぞれの住様式、 住宅観の相違を最も顕著に示す住宅の要素を、疊の間と板の間の活 用の度合いと捉えていたと言える。そこでここでは、公庫の分類規 範に倣い、畳の間及び板の間の活用によって設計例を分類し、各改 訂版の変遷を見る。全ての居室が畳の間の設計例は、 51 年版では 6 割近くを占めていたが、改訂ごとに減少し、特に大幅な改訂が行 われた 66 年版以降ではでは 2 割末満となっている（表 4)。一方、 畳の間と板の間を併用した設計例の割合は、 51 年の当初 4 割弱で あったが、66 年版以降では全体の 8 割以上に及ぶ。板の間の部屋 のみによって構成されている設計例は、 51 年の段階で $2 \%$ と少数 であるが、その後さらに減少し、66 年版では $1 \%$ となる。このよ うに、公庫は、 51 年の時点で「新しい傾向」の一要素と捉えてい た板の間の居室を、畳の間の居室と併用しつつ、各改訂で平面図集 に積極的に採り入れたことが判る。

なお板の間の導入が最も積極的に行われたのは、食事のための 部屋である。 57 年以降追加された設計例のうち、板の間のある住 宅全てに食事室がある。すなわち居室の板の間化は、食事室におい て優先的に進められたと言える。先に述べたように食事室設置の背 景には、住宅改善の延長にある家事労㗢の軽減と生活様式の洋式化 があったと考えられる。この家事労㗢の軽減と関連して、食事室と 台所を直結、或いは一室に収めた形式の導入を設計趣旨に嵒った設 計例屯みられる ${ }^{35)}$ 。台所の直結している食事室の割合は、51 年版 の $81 \%$ から 66 年版の $98 \%$ に増加しており、66 年版では殆どの 食事室が台所と直結した配置になっていることが判る。また、公団 住宅等で見られる食事室と台所を一室に収めたダイニングキッチン 形式も、 51 年版の $5 \%$ から増加し、66 年版では食事室の半数を占 め、食事室を導入する中で、台所及び食事室のコンパクト化が図ら れたと言える。このように家事労働の軽減、生活の洋風化という生 活様式の変化を背景に、食事室を板の間化し、さらに食事室と台所 を一室化した形式を採り入れたと言える。

次に動線の形式に注目することで、設計例の平面形式の類型化 を試みる。日本の伝統的な形式の住宅では、目的の部屋に達するた めに、他の部屋を通り抜けるか、緑側を経由しなくてはならない不 便があったため、近代以降、その短所を補う方法として中廊下型や 居間中心型に代表される新しい平面形式が導入された ${ }^{36)}$ 。5 1 年版 には、中廊下型が最も多かったが、目的と異なる室を介した動線を 持つもの（通り抜け型・図 4）や、片廊下型のもの（図 5)、居間
中心型のもの、住宅全体がほぼ一つの空間で構成され、部屋から部 屋への動線という概念が不明確なもの（一室型・図 6) まで、多様 な形式が含まれていた。

この平面形式の分類は、畳の間あるいは板の間の活用度合いと 相関がみられる。すなわち、51 年版で居室が全て畳の間である設 計例では中廊下型のものが最も多く、板の間の居室を持つ設計例で は居間中心型が最も多い（表 4)。また、居室の全てが盢の間である 設計例には、居間中心型及び一室型がみられない。そこで、板の間 の居室の有無と上で示した平面形式の分類を複合させ、設計例の類 型化を行うこととした。この分類によると、設計例を多く含む上位 3 位は、全ての居室が畳の間の中廊下型（図 7)、一部の居室が板 の間の中廊下型（図 3)、居間中心型（図 8）の三つの形式であり、 全ての時期においてこれらが全住宅例の 90\%以上を占めている。

これらのうち、当初最も多くの設計例を含んだのは、畳の間の みの中嫏下型の住宅であり、51 年版では 126 件で全体の半数以上 を占めていた。その 126 件のうち 71 件がメートル法移行前の 64 年版まで形を変えずに揭載されていた。また、51 年版から 75 年 版まで一貫して揭載されたとみなせる設計例が 19 件あるが ${ }^{37) 、 そ ~}$ のうち 14 件がこの形式であった ${ }^{38)}$ 。この平面形式は戦前に広く普 及していた住宅形式を原形としたものであったが ${ }^{39)}$ 、その通俗性 から、戦後も日本の庶民住宅として高い普遍性を持ったと言える。

しかし、66 年の改訂に際に、最も多くの設計例を含むものが、 畳の間のみの中廊下型から、居間中心型に移行している。ただし、

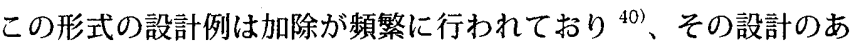
り方は模索の過程にあったと捉えられる。すなわち公庫は居間中心 型を新しい庶民住宅のあり方として位置付け、60 年代後半以降最 も主要な形式を畳の間のみの中廊下型から移行させたと言える。

板の間のある中廊下型は、各改訂でその割合が増加しており、 66 年版からは、畳の間のみの中廊下型より多くの設計例を含むも のとなる。畳の間のみ中廊下型の一部の居室を板敷にしたものであ り、主に食事する居室の椅子座化が反映されたことにより、増加し たと捉えられる。しかし、66 年の改訂により、曽の間のみの中廊 下型に替わって、板の間のある中廊下型が最も多数を占める形式に なったわけではなく、居間中心型が最も多くの設計例を含む形式と なったことから、折㖜性の強い板の間のある中廊下型は過渡的な性 質を持つ設計例と位置付けられていた可能性が窺える。

これらの3形式以外の住宅例については、改訂毎にその割合が 減少傾向にある。畳の間のみの通り抜け型、板の間ありの通り抜け 型は、動線の不合理に対する批判から削除されていったと考えられ る。一室型は、当初より 1 件しか採用されておらず、件数に増加が 見られないまま、 57 年版では削除されている。50 年代の建築家に よる斬新な住宅作品にもみられた形式であったが ${ }^{41)}$ 、戦後日本の 庶民住宅の形式として受容れられなかったと言える。

これらの設計例が削除されていったことにより、上述の 3 類型の 占める割合は改訂ごとに増加し、66 年版以降ではほとんどの設計 例がそれらに含まれることとなった。このように、初期の平面図集 には、伝統的な住宅形式から一室型形式など特殊な形式まで掲載さ れおり、50 年代の平面図集には多様な設計例が採りこまれていた が、66 年版では伝統的あるいは特殊な平面形式は削除され、3 形 式に絞り込まれていった。すなわち、公庫は当初、戦後日本の庶民 
表 4 平面図集の設計例の平面形式の概要 （板の間の活用、食事室、子供室の設配及び台所の配目）

\begin{tabular}{|c|c|c|c|c|c|c|c|}
\hline \multicolumn{2}{|c|}{ 発行年 } & 1951 & 1955 & 1957 & 1964 & 1966 & 1975 \\
\hline \multicolumn{2}{|c|}{ 総事例数 } & 240 & 350 & 300 & 222 & 185 & 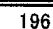 \\
\hline \multirow[t]{3}{*}{ 板の間の活用 } & 嘼の間のみ & 142 & 186 & 158 & 114 & 35 & 35 \\
\hline & 板の間のみ & 5 & 8 & 2 & 2 & 2 & 2 \\
\hline & 量·板の間硑用 & 93 & 156 & 140 & 106 & 150 & 159 \\
\hline 食事室 & 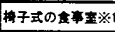 & 57 & 114 & 109 & 84 & 146 & 155 \\
\hline \multirow[t]{2}{*}{ 台所の配置 } & 全車坴と台所面結 & 46 & 83 & 82 & 66 & 143 & 152 \\
\hline & 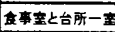 & 3 & 7 & 23 & 18 & 77 & 83 \\
\hline 子供室 & 子供室設置 & 7 & 25 & 24 & 19 & 79 & 87 \\
\hline
\end{tabular}

※1「食堂」「食事室」「居間」と記載のある居室、食卓などの記載のある居室及び台所に直結する板の 閂の居室を含む

表 5 平面図集の設尌例の功線形式と板の間の活用からみた平面形式の頶型

\begin{tabular}{|c|c|c|c|c|c|c|c|}
\hline 発行年 & & 1951 & 1955 & 1957 & 1964 & 1966 & 1975 \\
\hline 総亨例数 & & 240 & 350 & 300 & 222 & 185 & 196 \\
\hline 䱏の間のみ & 中廊下型 & 126 & 161 & 133 & 97 & 33 & 33 \\
\hline & 片廟下型 & 6 & 13 & 10 & 8 & 1 & 1 \\
\hline & 通り抜け型 & 10 & 12 & 15 & 9 & 1 & 1 \\
\hline 板の間あり & 居間中心型 & 54 & 90 & 78 & 56 & 84 & 83 \\
\hline & 中廊下型 & 37 & 67 & 58 & 49 & 68 & 78 \\
\hline & 片廊下型 & 4 & 3 & 2 & & & \\
\hline & 通り抜け型 & 2 & 3 & 4 & 3 & & \\
\hline & 1室型 & 1 & $\overline{1}$ & & & & \\
\hline
\end{tabular}

表 6 住宅・建築雑伅に揭戴の『木造住宅平面图集』に関する論考

\begin{tabular}{|c|c|c|c|c|c|}
\hline 蓄者 & 題名 & 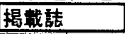 & 発行 & 揭载時期 & 頁 \\
\hline 大西克仁 & 公庫の䊅篗住宅钤計図にこつて & 住宅金融月報 & 住宅金融普及協会 & 1951.3 & \begin{tabular}{|l|}
21 \\
\end{tabular} \\
\hline 森田茂介 他 & 1951年の建築界を鯃る & 建築文化 & 培国社 & 1952.1 & $42-46$ \\
\hline 大西克仁 & 公庫の櫝準住宅設計图にこつて & 住宅金融月報 & 住宅金融普及協会 & 1952.4 & \\
\hline 山口登 他 & 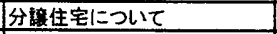 & 住宅金融月報 & 住宅金融普及協会 & 1955.3 & $11-18$ \\
\hline 富网三郎 & 害呯木造住宅平面図集 & 住宅 & 日本住宅協会 & 1955.11 & $32-33$ \\
\hline 前田昌靖 & 「本造住宅平面图集」巨ついて & 住宅金融月報 & 住宅金融普及協会 & 1956.4 & $31-37$ \\
\hline 早川文夫 & 大衆に好まれる平面について & 新建築 & 新建築社 & 1956.9 & $59-61$ \\
\hline 上松昭摹 & 特集平面図集を考えよう & 公庫融資住宅 & 住宅新報社 & 1968.3 & $2-19$ \\
\hline
\end{tabular}
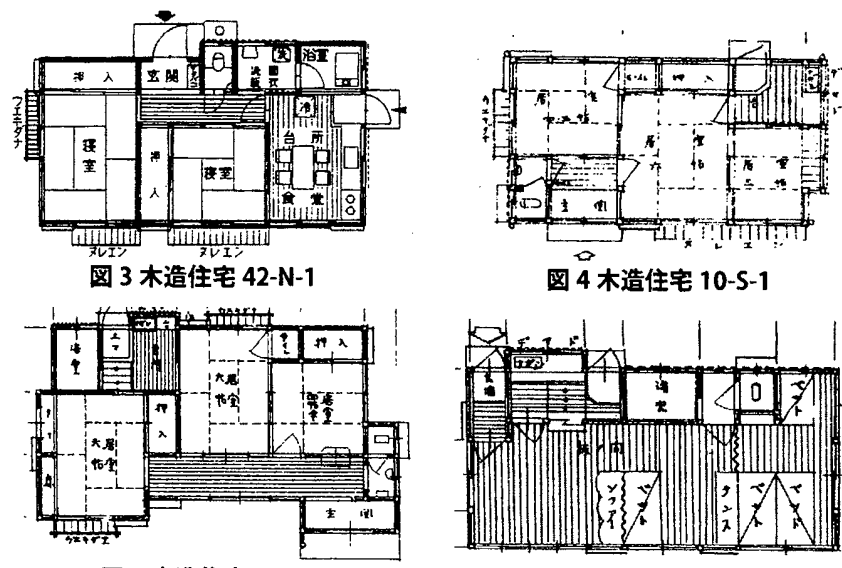

図 5 木造住宅 15-S-2

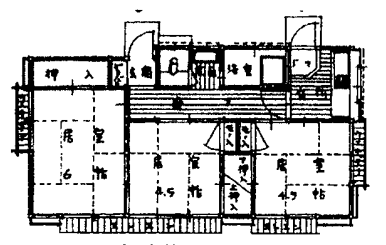

图 7 木造住宅 13-N-1

図 3,8:『メートル法にみる住宅平监図体』(1966.4)

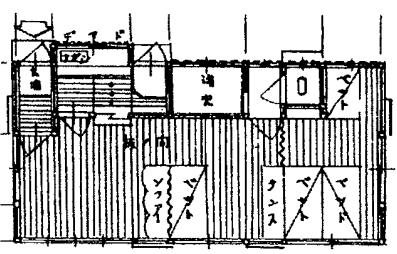

图 6 木造住宅 11-N-7

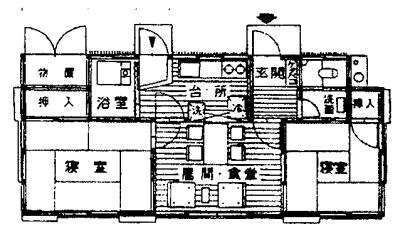

图 8 木造住宅 42-N-1

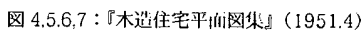

住宅のあり方を模索し、多様な標準住宅設計図の提示に重点をおい ていたが、60 年代中頃までに公庫の示す住宅像は収斂していった と捉えられる。

\section{4 平面図集揭載の設計例の社会的評価}

標準住宅設計図は、主に公庫住宅の施主を対象に頒布された。 標準住宅設計図の購入申込状況は、公庫の提示した設計例に対する 住宅建設希望者の評価を示すものとして注目に值する。標準住宅設 計図の購入申込に関するまとまった資料は残されていないが、ここ

では標準住宅設計図の購入申込状況について述べた 2つの雑誌記事 からその一端を明らかにしていく。2つの記事とは『住宅金融月報』 56 年 4 月号の「「木造住宅平面図集」について」 ${ }^{42)}$ と、『公庫融資 住宅』 68 年 3 月号の「平面図を考えよう」 ${ }^{43)}$ である。

申込の多かった標準住宅設計図の規模について、56 年では 15 坪以下への申込が過半数を占め、18 坪以下では 8 割弱に上ると記 されている。68年では $40 \sim 66 \mathrm{~m}^{2}$ (約 $12 \sim 20$ 坪) の設計例が 過半数を占め、 $75 \mathrm{~m}^{2}$ (約 22.7 坪) 以下のものが 8 割を占めたとさ れている ${ }^{44)}$ 。このことから、日本における一般的な住宅の規模が 拡大傾向にあったことが窥える。それぞれの記事の出された直前 に刊行された平面図集をみると、55 年版の設計例の平均規模は、 17.4 坪であり、当時の申込状況より床面積が大きい設計例が多く 含まれていたことから、公庫が床面積の拡大を促す先導的な役割を 担うことを意図していたと言える。一方、66 年版では、 $40 〜 66$ m゙ $58 \%$ を占め、ほぼ 68 年の記事の申込状況に等しいと言える。

56 年の記事には、申込の多い設計例が 17 件、平面図とともに 示されている ${ }^{45)}$ 。その内容をみると、全ての居室を畳の間とした ものが 13 件あり、板の間の食事室を持つものは 3 件のみであった。 最も申込の多い住宅は「15-S-2」という片廊下型の住宅であり（図 5)、2 番目から 5 番目は中廊下型の設計例であった（図 7)。この ことから戦前から普及していた形式の住宅への申込が多かったこと が判る。一方、55 年版の平面図集には、板の間の食事室を導入し た事例が 3 割含まれていたが、こうした設計例に対する申込は概 して少なかったとされる ${ }^{46)}$ 。また、䀣賞設計競技の当選案として 採用されたものなど、建築家による先鋭的な設計に対する申込はほ とんどなかったとの記述がある ${ }^{47)}$

すなわち、公庫の標準住宅設計図は、当時の施主一般の住宅観と 比べると、先進的な発想を多分に含むものであり、住宅改良の思想 を背景に、今後の住宅のあるべき姿を提示する意図を含むものであ ったと言える。しかし、公庫の提示した新しい形式の設計例は、広 い層に受容れられるものではなかったと言える。

こうした状況に関し、平面図集が住宅の設計に対して、より指 導的な意味を持つべきだという主張が同時期にみられる ${ }^{48)}$ (表 6)。 例えば、建築家の森田茂介氏は公庫住宅に関する 55 年の座談会で、 平面図集に揭載された設計例の多様性を評価しつつも、日本の住宅 の理想像を提示しておらず、指導性が欠如している点に難色を示し ている ${ }^{49)}$ 。その発言を受けて、標準住宅設計図作成の担当部署で ある公庫の建設指導部の山口部長は、公庫の設立から 5 年間、健 康で文化的な住宅の確保を優先してきたが、今後は「方向をもつた ものを作りたい、そういう平面図集作成に移りたい」との展望を述 べている ${ }^{50)}$ 。その後改訂された 57 年版の平面図集に、「これから は標準的な設計というより、寧ろ一つの新しい設計例」として提示

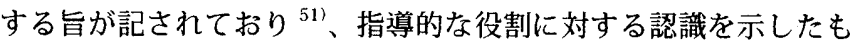
のと捉えられる。ただし座談会において山口氏は「生活の理念」「一 般の建築家の理念」に偏らず、「一般の今のひとたち」の現実とう まくバランスさせることの重要性も強調している。

同じく公庫職員であった早川文夫氏も、56 年に書かれた別の記 事で、「建築家が一人よがりの冒険」をすることなく、日本の住宅 の改良を進めて行く上では、「非常に長い時間をかけて、徐々に行 う根気」が必要であると述べている ${ }^{52) 。 ~}$ 
山口氏と早川氏の主張に通じるのは、日本の伝統的な住宅が好 まれる傾向を容認しつつ、将来的には家事労衝の軽隇や就寝分離等 を通じ、日本の住宅は改善されていくべきという確信と、その早急 な実現は不可能であり、徐々に進展を促していくべきとする方針で ある。こうした方針は、公庫の当初からの基本姿勢と重なるもので あり、平面図集に通俗性の高い伝統的・保守的な設計例と進取な設 計例を含んだことの思想的な背景と言える。

次に 68 年の記事から、申込の多かった設計例の全般的な傾向に ついてみる。それによると、申込の約 40\%が畳敷の居室のみの「純 然たる和風住宅」の設計例であり、畳への依存度が強かったことが 示されている一方、椅子式の食事形式を持つものが約 $60 \%$ にも及 んでいたという53。56 年の状況と比べると、依然、伝統的な日本 の住宅を好む傾向も継続しているが、椅子式の食事室の普及がかな り進展したと言える。また、ソファーやテーブルを配した板の間の 居間が好まれる傾向もみられ、日本人の住宅像が変化していった状 況が窥える。

同記事には、 66 年版掲載の 187 種のうち、31 種の平面図が掲 載されている。それらの全てが申込の多い設計例として揭載された ものではないが、 $40 \mathrm{~m}$ 程度の設計例として揭載された 3 つについ ては、何れも申込が多かったことが明記されている。その3つには、 「ダイニングキッチンと独立した寝室 2 室を組み合わせ」たもの、「3 寝室ともにフスマで仕切ったいままでの和風住宅」「板の間の居間 を中央に東西に和室を配し、台所と食事室をハッチで結んだ戦後の 新しい小住宅の典型」と解説が記されている ${ }^{54)}$ 。これらは、前節 で用いた分類に照らせば、それぞれ板の間のある中廊下型、盢のみ の中鄉下型、居間中心型に対応するものと言える。こうした保守的 及び進取的と捉えられる住宅形式が、いずれも支持されており、公 庫はその対応として、施主それぞれの要望に適うよう、上述の3つ の形式の設計例を平面図集に含ませたと言える。

なお、68 年において申込の多い設計例の $40 \%$ が依然として「純 然たる和風住宅」であったが、公庫は 66 年の改訂に㧧いて、居室 を畳の間のみとした設計例を2割以下に減らし、板の間の居室をも つ設計例を 8 割以上としている。これは上で見たように椅子式の食 事室の普及が広まりつつある状況を踏まえ、食事室を持つ設計例を 積極的に導入したもの推察される。

これらのことから、公庫は日本人の生活習慣の動向を捉えつつ、 平面図集を通じ、現状よりやや進歩的な住宅像の提示を意図してい たと言える。

\section{5 まとめ}

以上のように、木造住宅の標準住宅設計図を揭載した平面図集 の刊行は、 51 年より 75 年まで継続的に行われてきた。 66 年の改 訂以降、75 年の 1 回のみで、主に 50 年代から 60 年代半ばにか けて行われてきたと言える。各改訂版に揭載された住宅をみると、 50 年代において、公庫は当時の標準住宅設計図の購入申込の状況 よりも床面積の大きい住宅を提示して扔り、当時の実態に対して床 面積の増加を促していたと言える。さらに、申込まれる住宅の床面 積の増加に合わせるように、揭載の設計例の床面積を漸次増加させ ており、さらに 55 年には 2 階建てを採りこんでいる。その規模の 拡大は、各単位空間の拡大よりはむしろ、食事室や子供室等所要室
の増加、浴室及び洗面室等設備の拡充及び洗濯機や冷蔵庫等家電の 置場の確保への対応に起因すると言える。すなわち、日本人全般の 生活水準の向上による生活スタイルの変化への対応によるものであ ると言える。

標準住宅設計図の申込の実態を通して、50 年代半ばにおいては、 戦前から普及していた畳敷の住宅に対する施主の需要が高かったこ とが判る。これに対して、60 年代後半には、引き続き保守的な住 宅への需要も高いものの、食事する居室の椅子座化の普及や居間中 心型の住宅に対する受容の萌芽がみられた。言い換えれば、50 年 代から 60 年代にかけて、生活改善で提唱された住宅像が日本人一 般により広く受容されたと推測できる。

50 年代初期において、公庫は住宅としての基本的な性能の確保 と、標準住宅設計図を利用した適切な住宅建設、融資住宅の普及 を優先していた。各設計例の設計においても、当時の施主一般の住 宅観に比べれば、多分に先進的な発想を持っていたとは言え、多様 性を旨として、公庫としてあるべき住宅像は示さなかった。一方、 60 年代後半には、メートル法移行に伴う大幅な改訂があり、通俗 的且つ保守的な間取の設計例を継続して採用することへの留意もみ られるが、保守的な生活様式からの脱却を促し、椅子座式の食事室 やダイニングキッチンなど新しい住様式を提示することへの積極的 な姿勢もみられる。すなわち、公庫は平面図集の改訂を通して、日 本人の生活スタイルの動向に合わせ、日本人一般の住宅像に比べて、 より進取な住宅像を提示することで、融資住宅及び住宅一般の改善 を図ったと言える。

戦後日本の住宅像は、建築家や公的機関の技術者の提案と、居 住者を含む日本人一般の現実の保守的な住宅像との間の運動の中に 成立したと言えるが、公庫の平面図集はその過程を具体的に示すも のと位置付けられる。本研究では平面四集を通じて申込の実態から 推測される日本人一般の住宅像の傾向と、公庫の描いた住宅像を明 らかにしたが、戦後 50 年代から 60 年代における日本人の住宅像 は保守的なものと進取なものとの間で流動的に変容したと言える。

\section{謝辞}

本研究を進めるに当たり、前田昌靖氏（住宅金融公庫元職員）及び

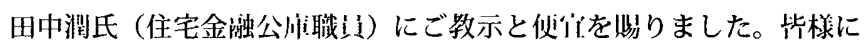
心から感謝し、誌上より謹んで胙礼申し上げます。

注

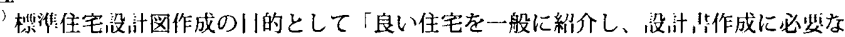
経費作成に必要な節減を計り、同時に審査手続きを簡略にするなど、融資希望者の 便宜を図るため、直ちに実施に移せるような標準住宅設計図を定める」との記述が ある。(大西克仁：公庫の標準住宅設計図について、住宅金融月報、19513、p21)

2) 住宅金融公庫の融資条件には、9 坪以上 30 坪以下の規模と台所及便所の設置とがあ る（住宅金融公庫建設指導部監修：住宅金融公庫融資住宅建設雷査基準、住宅金融 庫融資住宅建設基準と解説 附住宅金融公庫関係法規、警眼社、1950.8、pp3-41)。 また、1965 年には規模の上限が 120 mに拡大され、浴室の設置が義務付けられた(住 宅金融公庫編：住宅金融公庫例規集、住宅金融公庫、1967.3、pp27 31）。

3) 住宅金融公庫は、「庶民一般のための住宅」を対象とし、その住宅の質の向上を設立 の目的の一つとして揭げ、融資条件となる建設基準の作成など質の向上に関する施 策を行っている。なお、住宅金融公庫設立の経緯に関しては『住宅金融公庫 50 年史』 （住宅金融公庫総務部編、住宅金融公庫、2001.3）に詳しい。

4) 平井㕵『日本住宅の歴史』(日本放送協会出版、1974.4、p201)、山下和正『近代 日本の独立住宅の変遷』(都市住宅研究所、1984.2、pp47-48)、西山外三『すまい 考今学』（彰国社、1989.12、p357）、大川三雄他『図説近代日本住宅史』（鹿島出版会、 2001.2、p128）や宮本佳明他「住まいの戦後史ノート 7 ライフスタイル・プラ ン・部品」(『建築文化小、彰国社、1985.12、pp118 121)、では、公庫刊行の『木 造住宅平面図集』及びその改訂版に揭載された住宅を戦後住宅の事例の一つとして 取り上げている。しかし、これらは平面図集の住宅を統計的に検討したものではなく、

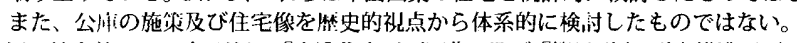

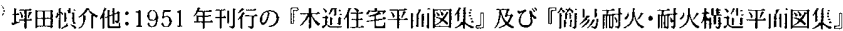
揭載の「標準住宅設計図」にみる住宅金融公庫草創期の住宅像、日本建築学会計画 
系論文集 604 号、日本建築学会、2006.6、pp183 189

6)门標準設計図の申込方法」(住宅金融普及協会編：木造住宅平面図集、新建築社、 1951.4、p6）には、掲載された事例は公庫から「標準住宅設計図」として購入可能 であることが明記されている。

?簡易耐火・耐火構造住宅平面図集』(住宅金融普及協会編：新建築社、1951.7)、 『燃えない家の設計四集』(住宅金虽普及協会編：新建築社、1953.7) 及び『ブロ ック造住宅平面図集』（住宅金融普及協会編：『ブロック造住宅平面図集』、新建築社 1955.4）と続けて、耐火の王建住宅に関する平面図集を発刊したが、1956 年以降、 刊行は行われていない。一方で、1951 年に刊行されたものと浦題の『木透住宅平 们図柋』が、1955 年、1957 年、1964 年に刊行されている。また、『メートル法 よる住宅平们図集』(1966.4)及びその改、汀版である『住宅平|们図集改、汀版』(1975.4) に関しても、設計図頒布の対象となるのは木造のみで、1964 年版とほぼ同一の瓦 面が含まれていることから、これら図集も『木造住宅平面図集』の一連の改訂版と 捉えることができる。

8) 住宅金融公庫が刊行した平面図集は、利用者がその書籍に揭載された平面図から住 宅案を選出し、設計図一式を申込むことができるカタログである。すなわち、公庫 は住宅案を選択する材料として、平面図のみでも十分であると判断したと言える。 このことから、平面図集に揭載された平面図を分析することで、公庫が利用者に対 して提示した住宅像を明らかにすることができると考える。

9) 本稿では、標集住宅設計図が揭載された以下の平面図集を扱う。 住宅金融普及協会編：木造住宅平面闵集、新建築社、1951.4 住宅金融普及協会編：木造住宅平面図集、新建築社、1955.4 住宅金融普及協会編：木造住宅平面図集、新建築社、1957.4 住宅金融普及協会編：木造住宅平面図集、新建築社、1964.3 住宅金融普及協会編：メートル法による住宅平面図集、新建築社、1966.4 住宅金融普及協会編：住宅平面図集改訂版、新建築社、1975.4

${ }^{10)}$ 住宅金融公庫総務部：住宅金础公庫十年史、住宅金融公庫、1961.3 前掲書：住宅金融公庫 50 年史

1)『住宅金融月報』（住宅金融普及協会、1951.2 創刊～1979.12）及び『公庫融資住宅』

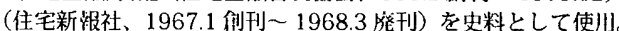

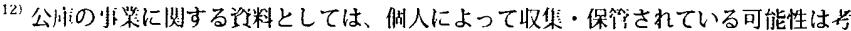
えられるが、本稿では公州および公的な论料䬦等において所咸が確認できる望料を 主に利用する。

13) 前揭書 : 木造住宅平面図集、1955.4、p4

14)『木造住宅平面図集』(前揭書、1957.4、p4)には、住宅に対する要求の変化に対底 することを目的とし、その変化に応じる平面を補充することの必要性が明示されて おり、その変化に関して、具体的には「第一は、とくに食事室や台所を主婦に衝き やすいように扱うこと、第二は、できるだけ将室を独立させること、第三は設備の 程度を上げること」との記述が見られる。

${ }^{15}$ 昭和 31 年度の「年次経済報告小、通称経済白書において「もはや戦後ではない」 と記述され、戦後復興による経済成長が謳われた。（前掲書：住宅金融公庫 50 年史、 p15)

16) 『木造住宅平面図集』(前揭書、1957.4、p 4)には、「これからは標準的な設計とい うより、寧ろ一つの新しい設計例としてご覧戴ければ幸いです」との記述がある。

7)序文」(前掲書『木造住宅平面図集』、1964.3、p1)には、改訂を行う目的として 「テレビ、電気冷蔵庫等家庭用電気製品の目覚しい普及、生活の洋風化に伴う居住形 式の変化、並びに住居水準の向上等によって住まい方に変化を生じてきたこと」と の記述がある。

${ }^{18)}$ 前揭書：序文、メートル法による住宅平面図集、1966.4、p3

19)『住宅平面図集改訂版』、(前揭書、p7)には、最近の住宅の質の向上は目覚しく 特に住宅の住まい方の変化によって、住宅の规模の水潄がかなり上がってきている

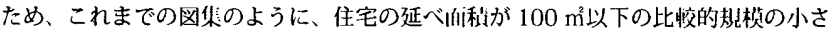
い住宅を中心としたものでは、状にそぐわなくなりました」との述がある。

20)「住宅口論」(住宅金融公庫職員：住宅金融月報、住宅金融普及協会、1979.11 p1）には、標準住宅設計図掲載の平面図集について、「途中何度も改訂を加えたも のの、平均規模が 100 mを越した現在、実情に添わないとと記述があり、公庫融 資を利用した個人住宅の平均規模が $100 \mathrm{~m}^{2}$ を超えたことを設計図頒布の廃止として 掲げている。また、標準住宅設計図頒布の廃止の背景に、当時公庫の職員であった 前田昌靖氏（1953 1987 年まで公庫勤務。なお前田氏へのインタビューは 2006 年 3 月に実施）より、100 m²以上住宅に対する確認申請制度の適用があったこと を何った。標準住宅設計図の制度は、建築士が関与しない既製の設計図を䗰入する という制度であることから、100 $\mathrm{m}^{2}$ 以上の住宅の設計図を頒布することが制度上で きなかったと言える。なお、1979 年 2 月の建築基準法改正により、100 m²上の 住宅新贸は建築士による確認申請の対象となる。（建設省住宅局:建築基準法第 6 条、 建築基準法令集改正普及版、日本建築学会、1981.7、p25)

21)「従来のものは、比 較的タタミの室を多く取っていますが、坪数の割に多人数が 住む場合には、このような平面が適しているので、申込の多かったものは全て残し てあります。」と記述がある。(前揭書：木造住宅平面図集、1957.4、p4)

22)『木造住宅平面図集』（前揭書、1964）揭載の「11-N-3」と『メートル法による住 宅平面図集』（前掲書、1966）揭載の「38-N-1」は、玄関の縮小と洗面室の拡大の 点以外ほぼ同一の平面である。また「10N-1」と「32-N-2」では、台所の面積に 関して、「32-N.2」のほうが大きい等、36 件中 34 件で平面の一部に変更がみられる。 ${ }^{23}$ 裎 2 参照

24) 14 坪以下の临例数の制合は、1951 年版では $38 \%$ (91 件) であったのに対して 1966 年版では $28 \%$ （52 件）と隇少している。また 22 坪以上の割合は、同期間て 13\%（32 件）から $21 \%$ (39 件) に増加している。

25) 居室には、「食事室」、茶の間」や「居間」など公室や「謾空」「子供室」など私室 を含む。台所、浴室や洗面室など設備に関する空間は含まないが、食事と台所を 室とした場合、その部屋は居室に含む。

26! 例えば「13-S-1」の設計趣旨には、椅子座式の食事室の設置及び子供室の設置 を設計趣旨として唱えている。「11-W 4」の設計趣旨には、子供室と夫婦の蟃室を
分けることによる誛室の增加に関する記述が見られる。（前掲書：木造住宅平面図集、 1957.4)

${ }^{27} 57$ 年以降の改訂で新たに作成された設計例 233 件中、椅子座式の食事室のある例 は 200 件あり、その割合は $86 \%$ に上る

28. 註 26 参照

29) 大正期の住宅改良運動において、住宅の洋風化、家族本位をもとに、椅子座式の食 事室の設置が提唱された（木村徳国：中廊下型·居間中心型住宅様式の設立、北大工 学部研究報告、北海道大学、1958.7、pp151-174)。また、子供室の設置は、終戦

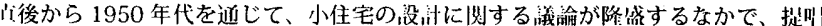

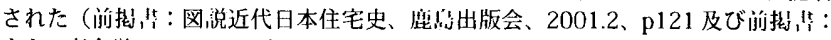
すまい宩今兴, pp321322)

30) 家事労衝の軽隇は、「18 S 7」の設計趣旨の中で、食事室の椅子座化及び台所と直 結に配置することに言い換えられている。そのほか 1957 年版の設計趣旨のなかで は、食事室と台所の一室化や台所の南面配置、水廻りを集めることで動線を短くす ることに言い換えられている。（前掲書：木造住宅平面図集、1957.4）

日本の平均世帯人数は当時から減少傾向にあり、寢室や子供宾の増加は、家族 の人数の增加への対応を目指したものではなく、就寝分離を進めるためのものて あったと判断できる。(日本統計協会編：日本長期統計総覧第 1 巻、日本統計協会、 1987.11、p168)

${ }^{32)}$ 前掲書：住宅金融公庫融資住宅建設審查基準、住宅金融公庫融資住宅建設基準と解 説

${ }^{33)} 1963$ 年の総理府による調查結果から、調查対象総戸数 20372000 戸に対して、浴 室のある住宅は 12047000 戸で、その割合は 59.3\%であることが判る。（前掲書 日本長期統計総覧第 1 卷, p12)

${ }^{34}$ 大西克仁：公庫の標準住宅設計図について、住宅金融月報、住宅金蛧普及協会、 1951.3、p21

35: 食事室と台所を直結及び一室に収めた形式の導入に関する記述は、それぞれ [15-W-8」、12-E-6」等の設計趣旨にみられ、家事の動線を簡略化する手法として 諨われている（前揭書：『木造住宅平面図集』、1957.4）。

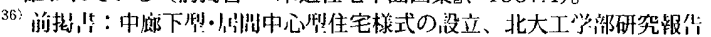

37 注 22 参煦

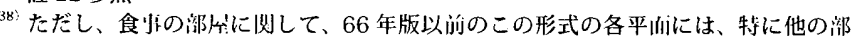
屋と区別されていないのに対して、66 年版以降設計例全てに「茶の問」と記述され た部屋が設置されており、公庫が 66 年の改訂以降、鳁の間のみの構成の住宅に関 しても食寝分離を意識していたことが判る。

39: 中廊下型の住宅は、大正期から昭和初期にかけて広く普及していたとされる。(前 揭書：中廊下型·居間中心型住宅様式の設立、北大工学部研究報告)

40) 1951 年に作成された 54 件のうち、64 年版では 17 件、1975 年版では 1 件しか 残されていない。

戦後活躍した建築家である柴岡亥佐雄、清家清や丹下健三はそれぞれ 1949 年 1954 年、1954 年に固定された内壁のない一室型の自邸を建てている。そして、そ れらは特殊且つ斬新な住宅として評価されている。(黒沢隆：近代・時代のなかの住 居改䛠版、メディアファクトリー、1993.8、pp120-125)

42) 前田昌靖：「木造住宅平面図集」について、住宅金融月報、住宅金融普及協会、 1956.4、pp31-37

${ }^{43 i}$ 上松昭義：特集平面図を考えよう、公庫融資住宅、住宅新報社、1968.3、pp2 19 4) 前掲畫：特集平面図を考えよう、公庫融資住宅

45)「木造住宅平面図集」について」(前揭書)には、申込の多い設計例として、20 部 以上の申远のあった設計例 19 件のうち、17 件の設計例に関して、その型番或い: プランが掲載されている。

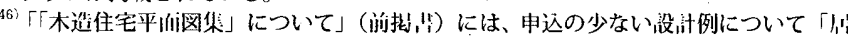

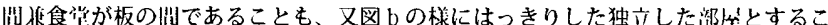

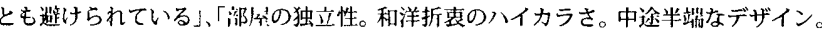
全洋室の住まい等ではなくてと云ってもあまり恰好の悪くないおとなしい平面を求 めているように見える」等の記述が自られる。

17) 公庫の職員であった前田昌靖氏は、㲘賞競技の入選案のうち、7 件の住宅に対する 申込がなく、また 1 件だけの申込を含めると 21 件にも及んでいることを記述した 上で、建築家と施主との住宅観の差を問題点として挙げている。（前揭書：「木造住 宅平面闵集」について、住宅金融月報)

48) 当時住宅公団の職員であった富岡三郎は、「書評 木造住宅平面図集、ブロック造 住宅設計図集、コンクリートアパート設計図集」(住宅、日本住宅協会、1956.11、

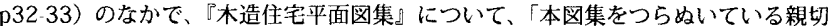
さからとかれる限り望ましい住み方の提示をすることはより意義のあることではあ るまいか。と記述し、指導的側面を持たせる必要性を主張している。

49)「分譲住宅について」（森田茂介、山口登他：住宅金融月報、1955.3，pp11-18）に おいて、森田茂介は『梏住宅平面図集』について、「あれはいろいるなバラエティ がありましたが、何にも主張がないような気がしたのです。(中略)もっとはっきり した、例えば今の日本なかではこういう住宅がいいんだという主張が欲しかったと 思います。(中略) 金融公庫としてある程度プランニングなどに对して、指導的意見 を持つほうがいじゃないかとということです。」との意見を述べている。なお、『木 造住宅平面図集』（前揭書、1957、p4）において、森田茂介は柴岡亥佐雄らと並んで、 標準住宅設計図の作成の携わった建築家とし挙げられている。

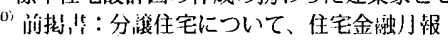

1) 16 参照

2) 早川文夫は「大衆に好まれる平面について」のなかで（新建築、新建築社、 1956.9、pp59-61)、『木造住宅平面図集』揭載の住宅を「住宅営団時代の平面から 余り進んでいないかもしれません。と評し、今後の展開について議論の余地がある ことを示唆しながらも、「新しい生活の創造」の提示の姿勢の必要性を指摘している。 ? 前揭書 : 特集平面図を考えよう、公庫融資住宅 ? 同上 